\title{
Leadership Challenges in the Implementation of Ict in Public Secondary Schools, Kenya
}

\author{
Laaria Mingaine ${ }^{1}$ \\ ${ }^{1}$ School of Management, Shanghai University, Shanghai, China \\ Correspondence: Laaria Mingaine, School of Management, Shanghai University, 99 Shangda Road, Shanghai, \\ 200444, China. Tel: 86-139-1651-0024. E-mail: mingainesl@yahoo.com
}

Received: December 4, 2012

Accepted: December 26, $2012 \quad$ Online Published: January 9, 2013

doi:10.5539/jel.v2n1p32

URL: http://dx.doi.org/10.5539/jel.v2n1p32

\begin{abstract}
Many authors argue that school leadership determines how Information Communication Technology (ICT) is implemented and its subsequent impact on teaching and learning. This involves Principal as a school leader to lead in implementation. A positive attitude of school leader towards implementation of ICT will encourage the school community to be actively involved in its implementation.

Kenya is in the process of implementing ICT in schools. However, there are many challenges that hinder effective ICT implementation including school leadership challenge. This paper reports that school leader's interest, their commitment and championing implementation of ICT programs in schools positively influences the whole process. The Paper recommends that all school leaders consider using ICT in their day-to-day activities of running their schools. ICT curriculum and managerial skills should be incorporated to training of school leaders in Kenya. Implementation of ICT is becoming more important to schools and the success of such implementation is often due to presence of effective school leadership.

To a large extent, school leaders have been relying on government and development partners to equip schools with ICT infrastructure. This Paper recommends besides sensitizing development partners and waiting for their contributions, school leadership should consider ICT a priority in school and allocate budgets that would promote its implementation. A descriptive survey was used to collect data by administering questionnaires to selected sample of ICT/curriculum teachers, Principals and Board of Governors (BOG) chairpersons from 105 public secondary schools in Meru County, Kenya.
\end{abstract}

Keywords: school leadership, implementation, ICT, schools, Kenya

\section{Introduction}

Research shows that investments in ICT for enhancing formal and non-formal education systems are essential for schools improvement (Tong \&Trinidad, 2010). School leaders are chief accounting officers in their schools and therefore are concerned in allocating budgets to various school activities including implementation of ICT. According to Betz (2011), implementation of ICT in schools would be successful when school leader supports, learns, provide up to-date infrastructure, adequate professional development and support staff during its implementation. School leaders have responsibility of supervising implementation of ICT programs in their schools. A study carried out by Anderson \& Dexter (2010) on technology leadership behaviors of school principals established that apart from ICT infrastructure being important in school, school leadership was the most determining factor in the process of effectively implementing ICT in schools.

More research support the idea that school leadership behavior determines success or failure of schools to implement ICT in its activities (Schiller, 2011, Hennessey, 2010, Aguyo, 2010, Chang, Chin \& Hsu, 2012). From these studies it can be concluded that school leader's behaviors is very important in implementation of ICT in schools. Researchers and authors view leadership behavior of educational managers has having a positive role in determining the process of ICT implementation in education. A positive behavior towards ICT would set clear visions and good conditions for its implementation. In schools, positive behavior towards ICT would manifest itself by the way the school leaders use ICT and encouraging others to use it. For efficient implementation of ICT in schools, school leaders must address challenges of implementing new technologies, starting with their own challenges. 
However, due to many challenges in implementing ICT in schools in sub-Sahara Africa, school leaders find themselves in a situation that requires them to understand and undertake some of these challenges. Failure to meet these challenges would mean many schools would not be able to effectively implement ICT in their teaching and learning activities. This would mean further widening knowledge gap, deepening existing economic and social inequalities between those who have access to and control technology and those do not.

Kenya Vision 2030 (GOK, 2007) implied that ICT could be used to propel the country to a middle level economy by improving security, lowering cost of doing business and providing Kenyans with a friendly working environment among others. Specific strategies were to include improving the quality of education by providing quality teachers, space and technology for delivery. Key to this was implementation of ICT in schools. Despite its importance and the strategies developed by the government on implementation of ICT in schools, research have established that many of them are not effectively using ICT to support learning, teaching, research and management as intended by Kenya National ICT policy. Meoli (2007) revealed that despite efforts made by various stakeholders and the importance of ICT in education sector, the National ICT policy have to a large extent remained in draft form. No attempt is made to implement the policies to schools. This necessitated examining school leadership challenges in implementation of ICT by asking "how does school leadership influence implementation of ICTs in public secondary schools in Kenya?"

\section{Scope of study}

In an attempt to investigate challenges faced during implementation of ICT programs in public secondary schools in Kenya, a study was carried out in Meru County. The study involved views of ICT/curriculum teachers, principals (school leaders) and BOG chairpersons on school leadership challenges in the process of implementing ICT in schools. This study covered only One County in the country; however, results of the study are likely to reflect what was happening in all public secondary schools in the country as they operated within the same guidelines set by Ministry of Education.

\section{Literature Review}

\subsection{School Leadership's Vision and Strategic Planning in Implementation of ICT in Schools}

School leadership should have clear visions and strategic plans for implementing ICT in their schools. Without clear vision and strategic plan by school leader, in implementation of ICT, it is likely that there would be poor coordination of activities and only enthusiast teachers' would battle to implement it to support learning. School leadership vision and strategic plans for ICT should be driven by pedagogical and not technological considerations.

Researchers warn of dangers of technological considerations where features of ICT drive decisions about its implementation in schools without pedagogical considerations. Technological considerations without a clear vision of how technology would affect learners have a danger of putting more effort on provision of ICT infrastructure rather than how ICT would help learners to learn. Technological thinking could be reduced through demonstrating clear visions, stranded with pedagogical understanding, and reflected in well constructed, short-term and long-term, strategic plans (Grono, 2010). The power and potential benefits of ICT should be considered in relation to other elements of school planning. Cost of implementation, staff ICT skills and development, benefits of implementing ICT in relation to other technologies, availability of electricity, school capacity to sustain implementation, among others, should all be considered during planning of implementation of ICT in schools by school leaders'.

\subsection{School Leadership's Role Modeling in Implementation of ICT in School}

School leaders are essential to creating a vision that empowers school community in setting to work cooperatively toward achieving instructional goals. Gurr (2010) observed that school leaders who are visionary, imaginative and inspirational helps to develop same qualities to his/her staff in school. School leader's visions of implementing ICT in school are realized through incorporating, developing and supporting visions of other school members.

In order to effectively perform duties of school leadership, school leader's roles should be geared in using ICT in school. They should demonstrate skills of using ICT in their day to day activities in school. They should be prepared to learn how to use ICT, but as learners, their understanding and competence in ICT need not be so complicated. Basic skills in using ICT are desirable. However, Bishop (2012) found that some school leaders' were not competence in basic ICT skills, though Gurr (2010) insists that present school leader should demonstrate some basic understanding of ICT in order to perform their duties effectively and inspire the school community to implement it. 
By using ICT, school leader demonstrates to school community that its implementation is important and he/she acts as a role model. Researchers have found that school leadership ICT role model for school community, is important in implementation of ICT programs in school (Gurr, 2010, Leach, 2011, Grono, 2010). Grono, (2010) argued that school leaders' who demonstrated high standards of profession modeled expectations of staff and students to perform their best.

Though school leader acts as a successful role model to school community during the process of implementing ICT in school, he/she should not be seen as the expert in ICT use. School leader acts as a link between staff who are ICT expect and the school. Schiller (2011) observed that school leader could act on advice from staff members competent in ICT during its implementation. The author asserts that it is sensible for school leader to seek assistance from other members of staff when making plans on how to implement ICT. School leaders demonstrating to be ICT experts while their ICT ability is not of high standards, would be unable to effectively implement ICT in their schools. They should model staff competent in ICT to take charge in its implementation, while they supervise the process.

\subsection{School Leadership in the Provision of ICT Infrastructure in Schools}

Lack of ICT infrastructure is a serious obstacle to implementation of ICT in schools, especially in developing countries like Kenya. Without these infrastructures, Kenya would not be able to implement ICT to schools to levels expected or required. ICT infrastructure planning and investments are therefore critical if Kenya's huge economic and developmental potential are to be realized. Key in helping schools implement ICT is careful construction of a sustainable infrastructure that could assist to turn the situation around.

School leaders are the custodians of school infrastructure, including ICT infrastructure. School leaders are concerned with providing adequate and relevant school infrastructure. It is the responsibility of school leader to make provisions of acquiring up to-date ICT infrastructure. Schools with up to-date ICT infrastructure encourage faster information sharing thereby creating less hierarchical and flexible organization, hence a more flexible learning environment within the school. School leaders, who recognize this, understand that their school could be more efficient and transformative (Grono, 2010). On this regard, school leaders should be in the forefront in championing implementation of ICT by involving all stakeholders in provision of ICT infrastructure in their school. They should actively lobby development partners and government to support implementation of ICT in their schools. It is the responsibility of school leaders to inform parents about expenses and importance of implementing ICT in school in order to encourage them to support the programs.

By providing adequate and up to-date ICT infrastructure, there is likelihood of staff professional development where staff learns as they use them in the process of teaching in school. This creates a good working school environment where staff and students feel valued and cared for (Hennessy, 2010).

Provision of up to-date ICT infrastructure in school would be a motivation for school staff not competent on ICT skills to train on them. Grono (2010) observed that, the method of providing ICT infrastructure before staff undergoes training, is becoming a popular approach in implementation of ICT in schools. More schools are increasing ICT infrastructure without sending their staff for in-service courses, such as supplying computers to classrooms so teachers are encouraged to try them. Through regular and consistent use of ICT, school leaders who are not competent in its use could develop the required skills.

School leaders should ensure that their offices have a computer and indeed they access it regularly, this way, they can learn more about the technology and therefore be able to encourage their school to adapt it. Unfortunately, very few school leaders in public secondary schools in Kenya have a computer in their office, most especially in mixed day secondary schools, where security of their offices is not guaranteed. Few mixed day secondary schools have a computer in bursar/secretary office. It should be noted here that the establishment of mixed day secondary schools in Kenya as expanded rapidly since the introduction of free secondary education. Most of these schools have taken over offices and classrooms previously used by the primary schools.

\subsection{Distributive School Leadership in Implementation of ICT in Schools}

Distributive school leadership involves leadership tasks of school being done communally by all members in a way that strengthen the whole school community, increasing a sense of commitment and collective responsibility while making tasks more manageable. Individual centered leadership is not appropriate in implementation of ICT in schools. Implementation of ICT in school should stem from a common vision concerning involvement of the whole school. Anderson \& Dexter (2010) observed that a distributive school leadership is emerging in schools due to implementation of ICT, hence promoting further school leadership reforms.

School leaders should delegate some roles of implementing ICT in school to other staff members. This would 
promote the personal belief by the staff in the importance of implementation of ICT in the school. The delegated ICT staff supplies school leader with advice on implementation of ICT in school. The school leader with cooperation of delegated staff and other school members can come up with ICT visions and plans, which can successfully help in implementation of ICT in school.

Grono (2010) argues that school leader who delegates some responsibilities of leadership to his/her subordinates helps create school environment where all members participates in decision making. This way, school leader empowers his/her staff to develop, create and own shared positive visions that are important in implementation of ICT. Therefore, it can be argued that encouraging others to lead imposes greater responsibility and initiatives on them.

A distributive school leader develops leadership skills to other staff members through delegation of some leadership. Delegating power within the school creates environment where staff share, work and learn together, leading to a collective purpose and universal goal. Unfortunately, research as established that the notion of distributed school leadership does not exist in many schools, though (Gurr, 2010, Hennessy, 2010, Grono, 2010 and Dzidonu, 2010) argued that through distributive leadership, differences between leaders and followers are minimized, hence opening opportunities for school staff to have a common stand regarding implementation of ICT in school.

Delegation of leadership, common decision making, provision of up to-date ICT infrastructure and professional development, motivates and empowers teachers. By empowering teachers to own the process, the school leader set educational goals for implementation of ICT in school by involving them in championing, promotion and development of ICT. This means that school leader leads the implementation of ICT in school without himself/herself being ICT expert. This way teachers' gets recognition for success, giving satisfaction and possession of directions and decisions arrived in school.

\subsection{Transformational School Leadership in Implementation of ICT in Schools}

Transformational school leadership is a type of school leadership style that leads to positive changes in school staff and students. Transformational school leaders are usually active, passionate and enthusiastic. These leaders are concerned and involved in the process of implementing ICT as well as helping all school members realize the dreams of ICT. Transformational school leader delegates' responsibility, shares decision making, promotes staff professional development and maintains a clear vision in school. This leader is capable of influencing others by aligning ICT vision with values of the school.

To be able to implement ICT in school effectively, school leader should be able to set goals, organize, manage, monitor and build relationships with other members of school community. He/she should be people centered who is able to model standards and practices consistent with culture of the school. Grono (2010) argued that transformational school leader should be a person having ideas for school that are allied to the school's standards. The author notes that, these are collective ideas that uplift teachers' and students' excitements, aspirations, provides principles for the school and allows school community to work together. School leader who is able to build and convey these ideas in form of an essential vision in his/her school displays an important leadership characteristic.

Transformational school leader should be able to raise the level of individual conducts that they are creative thinker, with a dedication to performance, professionalism, principles and standards. School leader's vision sets goals to be attained during implementation of ICT. Sweeney (2012) outlines the qualities of a successful school leader as the capability to lead change with clear vision and ICT skills. A vision that focuses in the implementation of ICT in school creates interest within the school that it cares about students learning.

A vision for implementation of ICT in school should focus on:

- Planning, organizing and funding

- Staff development and ICT infrastructure

- Implementation, improving access and equity

- Maintenance and sustainability of ICT infrastructure in schools

- Legal and moral issues of ICT in school

- Education theory, pedagogy and curriculum improvement

- General school administration

The essential aspect of being the school leader is about dedication to set visions, to work and cooperate with 
others in bringing these visions to realization. Schools try to implement ICT into their operations to improve students' learning by presenting flexible learning opportunities and improving school activities. Not only ICT improves student's learning but the whole school community requires being ICT competent. ICT in schools is emerging as an essential factor for schools to operate effectively and efficiently as organizations and as a teaching and learning tool within the school community. Further, school leader could use ICT as tool for monitoring the situation in his/her school. Thus, ICT could be used as a tool of management in school.

\subsection{Studies on School Leadership Supporting Implementation of ICT in School}

Researchers have argued that school leadership is a stronger predictor of teachers' use of ICT in teaching (Anderson \& Dexter, 2010, Gurr, 2010, Bishop, 2012). School leader who implements ICT programs and shares a common vision with teachers stimulates them to use ICT in school (Yee, 2000). For effective implementation of ICT in school there should be a strong school leadership to drive a well coordinated and designed ICT plans.

As quality of school leadership improves, so does likelihood of schools implementing quality ICT. Effective school leadership focuses on ICT infrastructure, ICT implementation, ICT leadership, learning theory, general teaching and general school leadership.

Wong \& Li (2008) conducted a study on factors that influenced implementation of ICT in eight schools in Hong Kong and Singapore. Their study revealed that leadership interest, promotion, collaboration, experimentation and teachers dedication to student-centered learning influenced implementation of ICT in school. Another study by $\mathrm{Ng}$ (2008) in 80 Singaporean secondary school teachers, found that school leadership with qualities of identifying and articulating a vision, promoting recognition of common goals, providing individualized support, offering academic encouragement and strengthening school culture, influenced implementation of ICT in schools A further study by Afshari (2012) on 30 school leaders in second-cycle institutions in Tehran, revealed that, relationship between school leader's level of computer competence influenced implementation of ICT in schools. These studies reveal that school leadership interest and competency in ICT could help improve implementation of ICT in schools by teachers.

Another study by Yuen, Law \& Chan (2011) in 18 schools in Hong Kong, found that school leaders are key change agent, exhibiting visionary leadership, staff development and involvement in implementation of ICT in schools. School leader should share ideas with other staff while focusing on implementation of ICT in schools. Grono (2010) observed that institutions exemplified by executive involving subordinates in decision-making, strengthened by ICT plans, effectively implements ICT in education.

\subsection{Situation of School Leadership Challenges in Implementation of ICT in Schools in Kenya}

Research indicates that effective school leadership makes a huge difference in student performance and assisting staff to implement change. The demands of a changing society have placed enormous demand on school leaders to make a change in the way they manage their schools. Technological changes over the past 20 years in Kenya have impacted society and subsequently school environment. Requirements for accountability in managing schools and meeting the needs of all students and teachers, coupled with demand of a digital society require a change in the way schools are managed in Kenya. Some school leaders are committed to implementing needed changes. They understand the potential and role of ICT, when it is coupled with a focus on learning, for developing a capacity for relevance change, while others do not.

School leaders who are not ready for ICT leadership transformation put a lot of effort to acquire ICT infrastructure. But when they provide them, very few, if any, use them in meaningful way; therefore lack the essential visions and knowledge to lead implementation of ICT in their schools. As well as providing the needed ICT infrastructure, School leaders should focus on how infrastructure affects teaching and learning in their school. To achieve this, school leaders should recognize that, the idea to implement ICT in schools is not only for school use, but also a transformation of teaching and learning (Afshari, 2012).

According to Langimia (2009) Kenya experiences many challenges in the implementation of ICT in schools due to the fact that it lags behind in information superhighway technology. In terms of telecommunication infrastructure expansion, development of fixed telephone network throughout Kenya has been below expectations. Therefore many schools lack fixed telephone networks, which is important for connectivity.

While many countries have achieved up to $41 \%$ implementation of ICT in schools, the percentage remains considerably small in Kenya. Implementation aims at utilizing ICT to support teaching and learning in school in order to achieve enhanced education outcomes. Given that the government of Kenya has acknowledged shortages of teachers in its secondary schools, ICT could be the answer to this problem, where the few teachers available could share information with thousands of students in schools. School leaders should be aware of the 
potential of ICT to bridge the gap of shortage of teachers and other supporting staff in their schools.

Though school leadership is central to implementation of ICT in schools, few studies have been done in Kenya on school leaders' capabilities and technological skills needed for proper implementation of ICTs. This is the fact, despite the arguments by researchers that, school effectiveness, school improvement, implementation of ICT, staff development and motivation, students' achievements and generally school change depends on capabilities of school leaders (Fooi et al, 2008, Hennessy, 2010, Schiller, 2010, Dzidonu, 2010 and Fullan, 2003). It is understood that implementation of ICT in schools, use of ICT in the wide public and provision of ICT infrastructure to Kenyan population is a recent initiative.

Lack of "technology" leaders could therefore be a factor influencing the implementation of ICT in schools in Kenya. For example, in a survey carried out by Kandiri (2012) in twenty one public secondary schools in Kenya, revealed that the majority (eighteen) did not have well formulated procedures, plans or strategies for implementation of ICT in their schools. The study revealed that only expressed views and ideas of the ICT teachers were available. Schools lacked visions and strategic plans to maintain and implement ICT to the required levels. This puts interest, commitment and championing of school leadership to implementation of sustainable ICT programs in Kenyan schools into question.

\section{Conceptual Framework}

Conceptual framework refers to how a researcher conceptualizes relationship between variables in a study and shows them graphically or diagrammatically. It shows independent variables and dependent variables and how they are related or influences one another Mugenda (2003). This paper adopted a conceptual framework important in identifying school leadership as a force behind implementation of ICT programs in schools. Lobbying development partners, Interest in ICT and provision of equipment and qualified staff have been identified as indicators of school leadership commitment, interest and championing of implementation of ICT programs in Kenyan schools as shown by the figure 1.

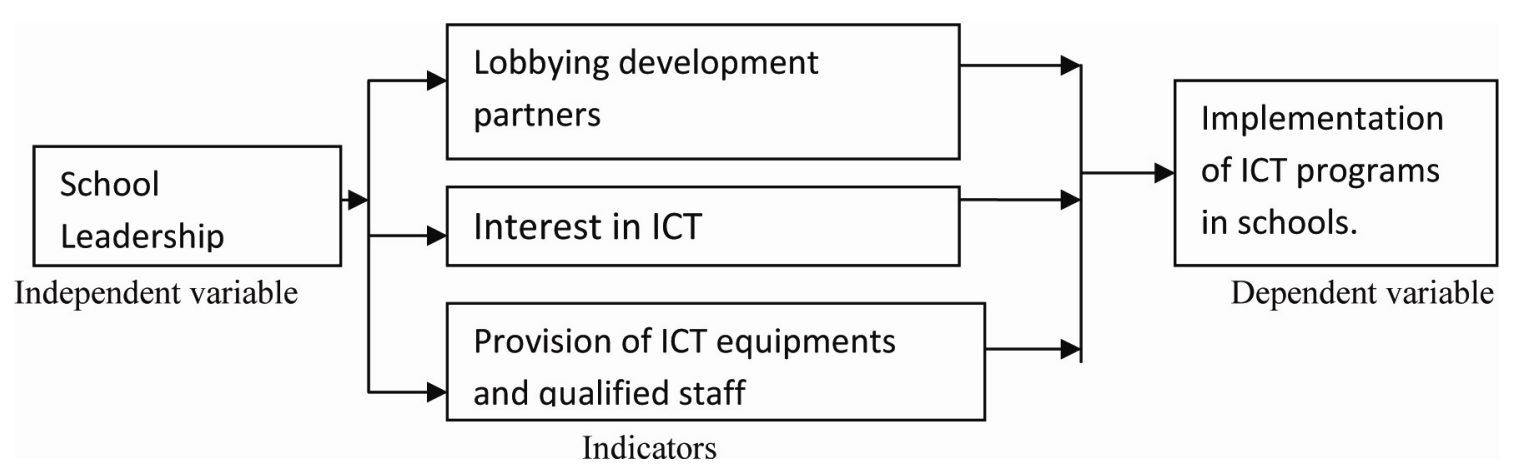

Source: Conceptualized by researcher, 2012

Figure 1. School leadership challenges in the implementation of ICT programs in school

The framework conceptualizes that school leadership interest, commitment and championing of implementation of ICT in schools is indicated by school leaders lobbying development partners to support implementation of ICT, their interest in using ICT and providing qualified staff and ICT equipments to their schools. The theory; if school leaders are lobbying development partners to support implementation of ICT in their schools, they use ICT in their management of schools and are committed in providing qualified staff and ICT equipment through allocation of funds; then they are interested, committed and are championing implementation of ICT in schools.

\section{Method}

A review of current literature reveals a diverse landscape in which it is apparent that there are many challenges to sustainable implementation of ICT programs in public secondary schools in Kenya, school leadership being one of them. This study was carried out in Meru County in Kenya. The County had 340 public secondary schools (as at June 2012) which were categorized as Boys secondary schools, Girls secondary schools and Mixed day/boarding secondary schools. A descriptive survey was used to collect data by administering questionnaires to selected sample of ICT/curriculum teachers, principals (school leaders) and BOG chairpersons from 105 public secondary schools in the County. The questionnaires were devised to explore the following issues: 
1) School leadership commitment to implementation of ICT programs in schools.

2) School leadership championing the implementation of ICT programs in schools.

3) School leadership interest in implementation of ICT programs in schools

The content validity of research instruments was ensured through experts' judgments competent in research techniques. Test and re-test method was used during pilot study to establish reliability of questionnaires.

\subsection{Sample Size and Sampling Procedures}

According to Kombo (2006), sampling procedures refers to how cases are to be selected for observation. It provides a detailed explanation of the subjects to be involved in investigation and how these are to be selected from the target group. According to Gay (2002) a researcher selects a sample due to various limitations that may not allow researching the whole population. Sekran (2007) says that sampling procedures and sample size are important to establish the representativeness of the sample for generalization.

Stratified random sampling method was used to select schools to ensure that all different subgroups were adequately represented in the sample, and then simple random sampling method was used to select respondents from various strata. Gay (2002) identifies random sampling as the best form of sampling as it allows all members of population to have an equal and unbiased chance of appearing in the sample. There were 26 boys' schools, 28 girls' schools and 56 mixed day/boarding schools. In all the schools sampled, the school leader, BOG chairperson and ICT/curriculum teacher were included in the study. Meaning there was three respondents per school in the sample. According to Levine (2007), statisticians have found that for many distributions, when a sample size is at least $20 \%$, the sampling distribution of the mean will be approximately normal (this is what is popularly referred to as the central limit theorem). Therefore, a sample of 315 respondents was representative enough for this study.

\subsection{Response Rate}

In any research, the response rate of the respondents is of importance as it reflects the in-depth of the data gathered. Data required for the study was collected through the use of questionnaires. A total of 315 questionnaires were distributed to the ICT/curriculum teachers, school leaders and B.O.G chairpersons. Out of the 315 questionnaires distributed, $220(69.8 \%)$ were appropriately filled and returned. The rest 95 (30.2\%) were either not returned or were partially filled, which meant discarding them during analysis. According to Mugenda (2003), a return of $50 \%$ and above is acceptable Therefore a return of $220(69.8 \%)$ of the questionnaires was considered acceptable for this research. The table 1shows the respondents' response data collected from field.

Table 1. Respondents response data

\begin{tabular}{lll}
\hline Respondents & No & $\%$ \\
\hline School leaders & 84 & 38.2 \\
ICT/curriculum teachers & 92 & 41.8 \\
B.O.G chairpersons & 44 & 20.0 \\
Totals & 220 & 100 \\
\hline
\end{tabular}

As shown in table 1 respond by the B.OG chairpersons was lowest, this was attributed to the fact that B.O.G chairpersons do not run day-to-day activities in Kenyan schools. The school leaders were requested to post/e-mail the questionnaires to B.O.G chairpersons, in this case it might have been most of school leaders did not post/e-mail or return the filled questionnaires from B.OG chairpersons to the researcher. The ICT/curriculum teachers had the highest respond followed by school leaders. The higher response by ICT/curriculum teachers and school leaders' respondents could be attributed to the fact that the researcher had a personal contact with them during administering the questionnaires.

\subsection{Gender of the Respondents}

Many studies have shown that there is a lot of disparity in education between genders, especially in Africa where emphasis is more to boy-child than girl-child. In the study, an overwhelming majority $150(68.2 \%)$ of the respondents were males while females were 70 (31.8\%). This implied that majority of leaders and ICT/curriculum teachers in public secondary schools in Kenya were men. Further it reviewed that most of school 
leaders who were involved in ICT in schools were males than females.

The study further revealed that in boys-single schools and mixed day/boarding schools, the majority of school leaders were males and only in girls-single schools that the school leaders were females. There was need for more females to take leadership roles in public secondary schools in Kenya.

\subsection{Age of the Respondents}

Introduction of ICT in Kenyan schools is relatively new phenomena; therefore the age of respondents is of interest in understanding the challenges in its implementation. Age group 30 and below were $22(10 \%), 31-40$ group were $56(25.5 \%)$, and $41-50$ were $92(41.8 \%)$ while over 50 years were $50(22.7 \%)$. Further analysis of age of the respondents revealed that the majority of ICT/curriculum teachers were below the age of 41 years. This indicated that the teachers who had knowledge of ICT were relatively young meaning that the introduction of ICT studies to Kenyan Tertiary/Universities was relatively recent and to extension in schools.

It was revealed that most of school leaders in Kenya were more than 45 years old; this was attributed to the fact that school leaders were appointed from the serving teachers who had shown desirable leadership qualities and had served the schools for some time. This indicated that most of them, without in-serve, had no considerable ICT knowledge that was necessary in the process of implementation of ICT programs in schools. Virtually all the B.O.G chairpersons were over 50 years old; this was due to the fact that most of B.O.G chairpersons were retired civil servants or business people who had been appointed to manage the schools.

\subsection{Duration of Stay in School by the Respondents}

The number of years an individual as worked in any station is of importance in explaining the experience gained in working in that station. Many respondents had been in the same school for a long period of time. Those who had worked for less than 3 years were $40(18.2 \%)$ while the rest had served the school for more than three years, $180(81.8 \%)$. This indicates that most of the respondents had witnessed the major developments that had occurred in the school and therefore one way or the other had experienced challenges in the implementation of ICT in their schools.

\subsection{Academic Qualifications of Respondents}

In any school, academic qualification of the school leaders' and the staff is very important as it reflects on their performance in school affairs. Table 2 shows the data of academic qualifications of the respondents.

Table 2. Distribution of academic qualifications in schools

\begin{tabular}{lllllllllll}
\hline Respondents & Bachelor & $\%$ & Master & $\%$ & Diploma & $\%$ & Others & $\%$ & Total & $\%$ \\
\hline School leaders & 58 & 26.4 & 16 & 7.3 & 8 & 3.6 & 2 & 0.9 & 84 & 38.2 \\
ICT/curriculum teachers & 62 & 28.2 & 14 & 6.4 & 13 & 5.9 & 3 & 1.3 & 92 & 41.8 \\
BOG chairpersons & 13 & 5.9 & 8 & 3.6 & 14 & 6.4 & 9 & 4.1 & 44 & 20.0 \\
Totals & 133 & 60.5 & 38 & 17.3 & 35 & 15.9 & 14 & 6.3 & 220 & 100 \\
\hline
\end{tabular}

The data implied that majority of the respondents had attained University education and had undergone some basic teaching skills that were necessary for management of schools and in extension implementation of ICT in education.

\section{Findings and Discussions}

The study was designed to investigate school leadership challenge faced during implementation of ICT programs in public secondary schools in Kenya. Research findings are presented in tables. Statistical data in tables are supplemented with some discussions and explanations.

\subsection{School Leadership Challenge in the Implementation of ICT Programs in Kenyan Schools}

A t-test was used to get difference in means for each of indicator variable in relation to dependent variable. It helped in determining those variables that were significant so that they could be fitted in regression model. Table 3 shows results of t-test. 
Table 3. Result of the t-test

\begin{tabular}{lll}
\hline School leadership challenges & Respondents' No. 52 & Respondents' No. 168 \\
\hline $\begin{array}{l}\text { Commitment of school leaders to } \\
\text { implementation of ICT in schools }\end{array}$ & 4.66 & 3.88 \\
$\begin{array}{l}\text { School leadership lobbying } \\
\text { stakeholders to support ICT } \\
\text { programs in school }\end{array}$ & 4.56 & 3.68 \\
$\begin{array}{l}\text { School leadership using ICT in } \\
\text { results analysis }\end{array}$ & 1.00 & 1.47 \\
$\begin{array}{l}\text { School leadership using ICT in } \\
\text { budgeting (preparing payroll, } \\
\text { procurements) }\end{array}$ & 1.05 & 1.24 \\
\hline
\end{tabular}

Note. All these factors had $10 \%$ level of significance, which means that there is a $10 \%$ chance that relationship emerged randomly and a $90 \%$ chance that relationship was real.

As shown in table 3, in relation to whether school leadership was committed to implementation of ICT programs in schools, a five level likert scale was used. In the scale, (1) was for strongly disagreeing, (2) for disagree, (3) for undecided, (4) for agree (5) for strongly agree. The mean of responses in schools which were implementing ICT programs was 4.66 which tended towards (5). This stood for strongly agree while the mean of responses in schools which were not implementing ICT was 3.88. This tended towards (4) which stood for agree at $10 \%$ level of significance. This indicates that respondents were in agreement that school leaders were committed in implementation of ICT in schools.

In relation to whether school leadership was lobbing stakeholders to support ICT programs, in five level likert scale, mean of responses in schools which were implementing ICT was 4.56 which tended towards (5), which meant that respondents strongly agreed that school leadership was lobbing stakeholders to support implementation of ICT in schools. Equally, mean of responses in schools which were not implementing ICT programs was 3.68 which tended towards (4) which stood for agree at $10 \%$ level of significance. Given that the two categories of respondents were in agreement that school leadership was lobbing stakeholders to support implementation of ICT in schools, it could be argued that school leaders were championing implementation of ICT in schools. As Farrel (2007) argued, this could be attributable to government's desire to facilitate public-private partnerships to mobilize resources in order to support implementation of ICT in schools.

In relation to school leadership's interest in implementation of ICT in schools as evidenced by their use of computers for budgeting (like in preparing payrolls, procurements and other financial activities in the school), responses were 1 for (Yes) and 2 for (No). Mean of responses in schools which were implementing ICT programs was 1.05 which was approximately 1 meaning that respondents were in agreement school leaders had interest in ICT use. On the other hand, mean of responses in schools which were not implementing ICT programs was 1.24 which was approximately 1 meaning the respondents were in agreement that school leaders had interest in ICT at 10\% level of significance. This means respondents from both categories agreed that school leaders had interest in implementing ICT in their schools.

In relation to school leadership's interest in ICT as evidenced by their use of computers for result analysis, responses were 1 for (Yes) and 2 for (No). Mean of responses in schools which were implementing ICT programs was 1.00; meaning that respondents were in agreement that school leaders had interest. On the other hand, mean of responses in schools which were not implementing ICT programs was 1.47 which was approximately 1, meaning that respondents were in agreement at $10 \%$ level of significance. As both categories of respondents were of idea that school leadership had interest in implementation of ICT in schools, it implied that school leadership interest influenced ways in which ICT was being implementation in their schools. However, this contradicts views held by Meoli and Waema (2007) that school leadership in Kenya, has not been considering ICT a strategic priority for their schools, consequently allocating low operational budgets to ICT and have not been giving attention to the use of ICT to enhance education and research.

\subsection{Logit Regression Model}

Logit regression model is used to model dichotomous outcome variables. In this model, log odds of outcome are modeled as a linear combination of predictor variables. A logit regression model is used where dependent 
variable has yes/no response or can be coded as either (1) or (0). The model was used to ascertain school leadership challenges which were crucial to implementation of ICT programs in secondary schools in Kenya. All those indicators relating to independent variable that were found to be significance in t-test were regressed to help in predicting dependent variable on the basis of independent variable. Table 4 shows results of logit regression model obtained from SPSS.

Table 4. Result of logit regression model

\begin{tabular}{llllll}
\hline Variable Description & Coeff. & SE & Wald & SG & Exp(B) \\
\hline Commitment of school leadership to implement ICT & 0.389 & 0.629 & 0.298 & 0.085 & 0.678 \\
School leadership lobbying stakeholders & 0.319 & 0.287 & 0.631 & 0.085 & 1.362 \\
School leadership use of ICT & 0.311 & 0.386 & 0.649 & 0.075 & 0.827 \\
\hline
\end{tabular}

Indicators used in the study to show school leadership interest, commitment and championing implementation of ICT in schools included; school leadership lobbying stakeholders to support ICT programs in schools, commitment of school leadership to implement ICT and school leaders use of ICT. School leadership lobbying stakeholders to support ICT programs had $\operatorname{EXP(B)}$ as 1.362 with a significance of 0.085 . The other indicator, commitment of school leadership to implement ICT had $\operatorname{EXP(B)}$ of 0.678 with a significance of 0.085 . School leaders use of ICT had EXP(B) of 0.827 with a significance of 0.075 . This means that all indicators were significant at $10 \%$ level of confidence. This means that school leaders were lobbying stakeholders (championing) to support ICT programs in schools, committed in the implementation of ICT in schools and had interest in implementation of ICT in schools.

\section{Conclusions and Recommendations}

From the study, it was evident that school leadership supported implementation of ICT through lobbying stakeholders to finance its implementation. However at school level, as Meoli and Weama (2007) points out, school leadership might not have been considering ICT a priority and was such had been allocating very low budgets for implementation of ICT in schools.

In theory school leaders have supported implementation of ICT in their schools, they had put some effort to acquire ICT infrastructure. But when they provide them, very few, if any, use them in meaningful way therefore lack essential visions and knowledge to lead implementation of ICT in their schools. School leaders fear that ICT infrastructure would be damaged by teachers and student in the process of teaching and learning curtailed innovative use of the facilities by the school community. As well as providing the needed ICT infrastructure, School leaders should focus on how infrastructure affects teaching and learning in their school. To achieve this, school leaders should recognize that, the idea to implement ICT in schools is not only for school use, but also a transformation of teaching and learning.

To a large extent school leaders had been relying on government and development partners to equip schools with ICT equipments. Where this might had been the case as evidenced by respondents who did not strongly agree that schools leadership supported ICT implementation, this study recommends that on top of sensitizing development partners and waiting for their contributions, school leadership should consider ICT a priority in the school and allocate budgets that would promote its implementation.

School leaders should recognize that implementation of ICT in schools, is a necessary transformation of how teaching and learning is done, and a chance to attract new students looking for new and better learning environment. School leaders should play a leading role in promoting teachers' attitudes towards implementation of ICT in school. Unfortunately many school leaders are either passive or actually against implementation of ICT, mainly due to cost. They perceive ICT as costly devices that would consume limited funds that they have, as well as distract teacher's time, without evident of short-term returns.

Being visionary and strategic planners, role models and custodian of school ICT infrastructure, school leaders should have interest, committed and champion implementation of ICT in their schools. To achieve this, school leaders should involve staff through distributive leadership style where some leadership responsibilities are delegated to others. They should lead transformation of the school through being active, passionate and enthusiastic. They should be concerned and involved in the whole process of implementing ICT in school, through delegating responsibilities, sharing decision making with other teachers, promoting staff professional 
development and maintaining clear vision of the school. They should be people centered, creative thinkers, dedicated to performance, upholding professionalism and standards in the school.

To be able to lead implementation of ICT in school, school leaders should be able to apply basic ICT skills in their day to day management of their school. To this end, it can be recommended that all school leaders consider using ICT in their day-to-day activities of running their schools. ICT curriculum and managerial skills should be incorporated to training of school leaders. Refresher courses in ICT for school leaders should be arranged regularly by Ministry of Education in order to keep them up to-date with new developments in Information Communication Technology and education in general. Implementation of technology is becoming more important to schools and success of such implementation is often due to presence of effective school leadership.

Therefore it can be concluded that school leadership interest, commitment, and championing the implementation of ICT programs in schools influenced the way Information Communications Technology (ICT) programs were being implemented in public secondary schools in Kenya.

\section{References}

Afshari, M. (2012). Transformational Leadership Role of Principals in implementing Information Communication Technology in Schools. Life Science Journal, 9(1).

Aguyo, S. (2010). The Real cost of computer in schools. In Getao \& Werner (Eds.), Power up with information Technology. Archry Technology Management Ltd, Nairobi, Kenya.

Anderson, R., \& Dexter, S. (2010). School Technology Leadership: An empirical investigation of prevalence and effect. Educational Administration Quarterly, 41(1).

Andoh, C. (2012). Factors influencing teachers' adoption and integration of Information Communication Technology into teaching: A review of the literature. International Journal of Education and Development using Information and Communication Technology, 8(1), 136-155.

Betz, M. (2011). Information Technology and school; the Principal's role. Educational Technology \& Society, $3(4), 4$.

Bishop, P. (2012). Information Communication Technology and School Leaders. Handbook of Educational Leadership and Management. Edinburgh gate: Pearson Education Limited.

Chang, I., Chin, J., \& Hsu, C. (2012). Teachers' perceptions of the Dimensions and implementation of Technology Leadership of Principals in Taiwanese Elementary schools. Educational Technology \& Social, $7(3)$.

Day, C. (2012). Challenging the Orthodoxy of effective school leadership. International Journal Leadership in Education, 4, 39-56.

Dzidonu, J. (2010). The role of ICTs to achieving the MDGs in education: An Analysis of the Case of African Countries, Accra Ghana. Retrieved from http://www.ait.edu.gh

Farrell, G. (2007). ICT in education in Kenya. Retrieved from http://www.infodev.org

Fooi, F., Afshari, M., Baker, K., Luan, W., \& Sumah, B. (2009). Factors affecting teachers' use of Information and Communication Technology. International Journal of Instruction, 2(1), 78-98.

Gay, L. (2002). Education Research competencies for analysis and application (4th ed). Macmillan publishers: New York, USA.

GOK (2007). Kenya Vision 2030. Government printer, Nairobi Kenya.

Grono, W. (2010). ICT leadership in school education. A paper presented to the Australian Catholic University Conference 2010, Sydney Australia.

Gurr, D. (2010). The impact of Information Communication Technology on the work of school Principals. Learning \& Managing, 6(1), 63-67.

Hennessy, S. (2010). Developing the use of Information and Communication Technology to enhance teaching and learning in East African schools. Review of the Literature Aga Khan University Nairobi Kenya.

Kandiri, M. (2012). A survey on ICT Access and use in Kenya secondary schools. summit strategies ltd, Nairobi Kenya.

Kombo, T. (2006). Guidelines to Proposal and Thesis writing. Pauline publications Africa, Nairobi Kenya. 
Langmia, K. (2006). The role of ICT in the economic development of Africa: The case of South Africa. International Journal of Education and Development, 2(4).

Leach, J. (2011). Do new Information and Communication Technology have a role to play in achieving quality professional development for teachers in the global south? The Curriculum Journal, 18, 293-329.

Meori, S., \& Waema, J. (2007). Kenya Education Network. Nairobi.

Mugenda, O. (2003). Research methods. African centre for Technology studies, Nairobi Kenya.

Ng, W. (2008). Transformational leadership and the integration of Information and Communication Technology into teaching. The Asia- Pacific Research, 17(1), 1-14.

Schiller, J. (2011a). Working with ICT: Perceptions of Australian Principals. Journal of Educational Administration, 41(2).

Schiller, J. (2011b). Surfers or Spectators? Principals and ICT: Principal Matters Journal, 5, 30-41.

Sekaran U. (2007). Research methods for business and skill building approach (4th ed.). Willey India.

Sweeney, B. (2012). Management and Leadership in schools. Educational Leadership Journal, 56, 48-60.

Tong, M., \& Trinidad, S. (2010). Conditions and constraints of sustainable innovative pedagogical practices using Technology. International Electronic Journal for Leadership in Learning, 9(3).

Wong, E., \& Li, M. (2008). Framing ICT implementation in a context of educational change. A multi-level analysis School effectiveness and school improvement, 19(1), 99-120. http://dx.doi.org/10.1080/09243450801896809

Yee, D. (2000). Images of school principals Information and Communication Technology Leadership. Technology, Pedagogy and Education, 9(3). http://dx.doi.org/10.1080/14759390000200099 